\title{
Soil carbon sequestration in the dryland cropping region of the Pacific Northwest
}

\author{
T.T. Brown and D.R. Huggins
}

\begin{abstract}
Knowledge of soil organic carbon (SOC) changes that occur under different agricultural practices is important for policy development, carbon (C) marketing, and sustainable land management. Our objective was to quantify agricultural impacts on SOC sequestration for dryland cropping systems in different agroclimatic zones (ACZs) of the Pacific Northwest (PNW). Data from 131 SOC studies were analyzed to assess land management-induced changes in SOC, including the conversion of native ecosystems to agricultural crops, conversion from conventional tillage $(\mathrm{CT})$ to no-tillage $(\mathrm{NT})$, and alternative crop rotations and management practices. Cumulative probabilities of SOC change were developed for assessing uncertainties inherent in SOC studies and for informing SOC markets. These analyses showed that $75 \%$ of converted native land lost at least 0.14 to $0.70 \mathrm{Mg} \mathrm{C} \mathrm{ha}^{-1} \mathrm{y}^{-1}(0.06$ to 0.31 tn $\mathrm{C}$ $\mathrm{ac}^{-1} \mathrm{yr}^{-1}$ ) over an average of 55 to 74 years depending on ACZ. Converting from CT to NT was predicted to increase SOC at least 0.12 to $0.21 \mathrm{Mg} \mathrm{C} \mathrm{ha}^{-1} \mathrm{y}^{-1}\left(0.05\right.$ to 0.09 tn $\mathrm{C} \mathrm{ac}^{-1}$ $\mathrm{yr}^{-1}$ ) over 10 to 12 years in $75 \%$ of studies analyzed and was also ACZ specific. Compared to annual cropping, mixed perennial-annual systems would be expected to gain at least $0.69 \mathrm{Mg}$ $\mathrm{C} \mathrm{ha}^{-1} \mathrm{y}^{-1}\left(0.31\right.$ tn $\left.\mathrm{C} \mathrm{ac}^{-1} \mathrm{yr}^{-1}\right)$ over 12 years in $75 \%$ of ACZ 2 sites. Other conclusions were that (1) SOC databases are lacking for low precipitation areas of the PNW, such as the dryland wheat-fallow region; (2) baseline sampling of SOC prior to management change is largely nonexistent for PNW databases except for a few notable cases; (3) soil erosion processes have likely impacted SOC and contributed to large variability among studies; (4) sampling methodologies and analyses for SOC have been inconsistent, thereby contributing to SOC variability; and (5) a validated C model for the PNW would aid evaluation of SOC changes due to management, particularly for specific farms and sites with unique SOC history and circumstances.
\end{abstract}

Key words: soil organic carbon—carbon sequestration—-tillage—crop rotation

Soil carbon (C) sequestration has been proposed as a major agriculturally based strategy for mitigating rising atmospheric concentrations of greenhouse gases (Smith 2004). Developing sciencebased $\mathrm{C}$ policy, marketing, and improved management decision support requires a regional assessment of soil C sequestration rates under different agricultural land management scenarios. Soil organic carbon (SOC) is a balance between $\mathrm{C}$ additions from unharvested plant residues and roots, organic amendments, and erosional deposits and $\mathrm{C}$ losses through decomposition of organic materials and soil erosion processes (De Jong and Kachanoski 1988; Paustian et al. 1997). Conversion of native lands to agricultural production has resulted in $20 \%$

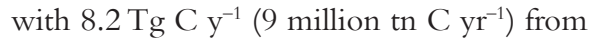
reducing tillage intensity (Sperow et al. 2003). Sperow et al. (2003) also estimated that adoption of $\mathrm{C}$ sequestering management practices could increase total US SOC stocks by 60 to $70 \mathrm{Tg} \mathrm{C}^{-1}$ (66 to 77 million

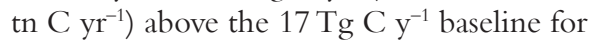
15 years following adoption. Rates of soil C sequestration following a change from conventional tillage $(\mathrm{CT})$ to no-tillage $(\mathrm{NT})$ are predicted to peak within 5 to 10 years and approach a new steady-state 20 to 100 years following a management change (Rasmussen and Collins 1991; West and Post 2002) or until the soil storage capacity is reached (Lal 2004). Consequently, SOC sequestration from changes in agricultural management has the potential to be a short-term mitigation factor in reducing atmospheric $\mathrm{CO}_{2}$ concentrations (Lal 2001; Smith 2004). In the northwestern United States, Liebig et al. (2005) reported average SOC increases of $0.05 \mathrm{Mg} \mathrm{C} \mathrm{ha}{ }^{-1} \mathrm{y}^{-1}\left(0.02\right.$ tn $\left.\mathrm{C} \mathrm{ac}^{-1} \mathrm{yr}^{-1}\right)$ for reduced tillage and $0.27 \mathrm{Mg} \mathrm{Cha}^{-1} \mathrm{y}^{-1}(0.12$ tn $\left.\mathrm{C} \mathrm{ac}^{-1} \mathrm{yr}^{-1}\right)$ for no-tillage under continuous dryland cropping. The SOC sequestration potential, rate of SOC accumulation, and time required to obtain maximum SOC, however, will be site specific.

Management-induced changes in SOC following an alteration in agricultural practice are often more pronounced at the soil surface compared to the subsurface. In comparing NT with CT, West and Post (2002) observed statistically significant SOC increases under NT of $4.8 \pm 0.87 \mathrm{Mg} \mathrm{Cha}^{-1}$ $\left(2.14 \pm 0.39 \mathrm{tn} \mathrm{C} \mathrm{ac}^{-1} \mathrm{yr}^{-1}\right)$ for the 0 to $7 \mathrm{~cm}$ (0 to 2.8 in) depth, but only $0.73 \pm 0.57 \mathrm{Mg}$ $\mathrm{C} \mathrm{ha}^{-1}\left(0.33 \pm 0.25 \mathrm{tn} \mathrm{C} \mathrm{ac}^{-1} \mathrm{yr}^{-1}\right)$ for the 7 to $15 \mathrm{~cm}$ (2.8 to 5.9 in) depth. No significant SOC differences between NT and CT were reported for the 15 to 25 (5.9 to 9.8 in) and 25 to $35 \mathrm{~cm}$ (9.8 to 13.8 in) depths studied (West and Post 2002). They concluded that approximately $85 \%$ of SOC sequestration occurs within the top $7 \mathrm{~cm}$ of agricultural soil when converting from CT to NT (West and Post 2002). Following conversion from annual cropping to permanent vegetation under the Conservation Reserve Program (CRP), Follett (2001) reported greater SOC

Tabitha T. Brown is a graduate student in the Department of Crop and Soil Sciences, Washington State University, Pullman, Washington. David R. Huggins is a soil scientist with the USDA Agricultural Research Service in Pullman, Washington. 


\section{Table 1}

Summary of collected soil organic content literature by management practice (native conversion [NC], no-tillage management [NT], reduced tillage management [RT], mixed perennial-annual system [Mixed P-A], Conservation Reserve Program planting [CRP], annual cropping, fallow cropping, residue burning, no residue burning, barnyard manure application, and green manure application) and Pacific Northwest agroclimatic zone (ACZ).

\begin{tabular}{|c|c|c|c|c|c|c|c|c|c|c|c|}
\hline \multirow[b]{2}{*}{$A C Z *$} & \multicolumn{11}{|c|}{ Management practice (number of studiest) } \\
\hline & NC & NT & RT & $\begin{array}{l}\text { Mixed } \\
\text { P-A }\end{array}$ & CRP & $\begin{array}{l}\text { Annual } \\
\text { cropping }\end{array}$ & $\begin{array}{l}\text { Fallow } \\
\text { cropping }\end{array}$ & $\begin{array}{l}\text { Residue } \\
\text { burning }\end{array}$ & $\begin{array}{l}\text { No residue } \\
\text { burning }\end{array}$ & $\begin{array}{l}\text { Barnyard } \\
\text { manure }\end{array}$ & $\begin{array}{l}\text { Green } \\
\text { manure }\end{array}$ \\
\hline 1 & 1 & - & - & - & - & - & - & - & - & - & - \\
\hline 2 & 8 & 12 & 3 & 9 & 2 & 16 & 9 & 1 & 1 & 6 & 14 \\
\hline 3 & 4 & 13 & 4 & 1 & 1 & 2 & 4 & 3 & 3 & 2 & 2 \\
\hline 4 & - & - & - & - & - & - & - & - & - & - & - \\
\hline 5 & 3 & 1 & - & - & 1 & - & - & 1 & 2 & 1 & - \\
\hline 6 & 1 & - & - & - & - & - & - & - & - & - & - \\
\hline
\end{tabular}

* The ACZ designations follow those presented in figure 1 of this manuscript.

† Number of studies by location rather than by publication (e.g., one publication may have data for three unique sampling locations and would be recorded as three studies).

changes in the near surface depth increment with SOC sequestration rates of $0.57,0.74$, and $0.91 \mathrm{MgC} \mathrm{ha}^{-1} \mathrm{y}^{-1}(0.25,0.33$, and 0.41 tn $\left.\mathrm{C} \mathrm{ac}^{-1} \mathrm{yr}^{-1}\right)$ at 0 to 5,0 to 10 , and 0 to 20 $\mathrm{cm}$ (0 to 2,0 to 3.9 , and 0 to 7.9 in), respectively. From these data it would be estimated that $63 \%$ and $81 \%$ of the SOC change from adopting CRP occurred in surface 5 and 10 $\mathrm{cm}$, respectively. These studies illustrate the importance of sampling depth for evaluating rates of SOC sequestration under different management regimes.

The large variability in reported soil C sequestration rates is a consequence of multiple factors that affect SOC storage including initial levels of SOC (Ismail et al. 1994) and degree of system SOC saturation (Hassink and Whitmore 1997); soil properties, such as texture and aggregation (Balesdent et al. 2000; Six et al. 2004); soil erosion (Chaplot et al. 2009); artificial drainage (Sullivan et al. 1997); soil disturbance and crop rotation (Huggins et al. 2007); productivity (Al-Kaisi et al. 2005); and time. Furthermore, sampling protocols, such as soil depth and time between sampling, can greatly affect rates of soil C sequestration. Our overall objective was to provide science-based information and assessment tools that quantify agricultural management impacts on rates of SOC sequestration for dryland cropping systems of the Pacific Northwest. Specifically we (1) identified where sufficient data sets exist in the Pacific Northwest (PNW) to assess management impacts on SOC sequestration; (2) combined SOC datasets with the same management treatments and located within the same agroclimatic zone (ACZ) to assess SOC changes with soil depth; and (3) assessed soil profile changes in SOC due to management on a cumulative distribution basis to further evaluate uncertainties associated with reported SOC changes that, in turn, would be useful information for policy development and/or carbon markets.

\section{Materials and Methods}

Overall, 131 location-specific SOC data sets were identified from peer-reviewed and nonpeer-reviewed literature (e.g., Agricultural Research Station Bulletins and Solutions To Environmental and Economic Problems Research Reports) that addressed changes in SOC content and distribution under agricultural management within the dryland cropping region of the Pacific Northwest (table 1). The geographic location of each site was identified within the approximately 3.3 to 4 million ha (8.2 to 9.8 million ac) of nonirrigated cropland occurring in the PNW (i.e., Idaho, north central Oregon, and eastern Washington) and classified according to agroclimatic zone (ACZ) based on Douglas et al. (1992) (figure 1). For each study site, duration of management, tillage, rotation, soil $\mathrm{C}$ data reported, sampling depth, landscape position, soil texture, soil series, annual temperature and precipitation, and method of SOC analysis were recorded. If annual precipitation or temperature were not provided, the location was assigned an agroclimatic zone based on its location relative to the ACZ map (figure 1). Only dryland cropping system studies were evaluated in this study, although some dryland locations identified were in the irrigated ACZ.

All data sets were converted from their original units to mass per unit volume per year ( $\mathrm{Mg} \mathrm{C} \mathrm{ha}{ }^{-1} \mathrm{~cm}^{-1} \mathrm{y}^{-1}\left[\mathrm{tn} \mathrm{C} \mathrm{ac}{ }^{-1}\right.$ in $\left.\left.^{-1} \mathrm{yr}^{-1}\right]\right)$ in order to (1) allow comparisons among the different studies by using the same units, (2) assess the depth-distribution of SOC change under different management situations, and (3) estimate total profile changes in SOC. Soil bulk density data are necessary to determine SOC on a volume basis. As several studies did not report bulk density values, bulk density values were assigned based on typical values for that soil type in order to convert SOC concentrations to SOC contents. Sensitivity analyses showed that the potential error from assigning bulk density values for sites lacking these data were relatively minor given the range of typical soil bulk densities of the region. The $\mathrm{Mg} \mathrm{C} \mathrm{ha}{ }^{-1} \mathrm{~cm}^{-1} \mathrm{y}^{-1}\left(\mathrm{tn} \mathrm{C} \mathrm{ac}^{-1} \mathrm{in}^{-1}\right.$ $\mathrm{yr}^{-1}$ ) units were derived by dividing the annual change in SOC by the depth sampled in $\mathrm{cm}$.

Sufficient data were available for a more comprehensive evaluation of soil $\mathrm{C}$ sequestration for (1) conversion of native vegetation (perennial) to cropland using tillage, (2) NT compared to CT management, and (3) use of a mixed perennial-annual rotation compared to an annual rotation. In addition, the limited data on effects of crop residue burning, use of green and barnyard manures, and CRP plantings on SOC were summarized.

In order to evaluate the affects of initial SOC on the rates of SOC change due to management, SOC changes ( $\mathrm{Mg} \mathrm{C} \mathrm{ha}{ }^{-1}$ $\mathrm{cm}^{-1} \mathrm{y}^{-1}$ [tn $\left.\mathrm{C} \mathrm{ac} \mathrm{in}^{-1} \mathrm{yr}^{-1}\right]$ ) were plotted against the initial SOC $\left(\mathrm{Mg} \mathrm{C} \mathrm{ha}{ }^{-1}\right.$ [tn C $\left.\left.\mathrm{ac}^{-1}\right]\right)$. Changes in SOC relative to initial C were presented for 0 to $30 \mathrm{~cm}$ (0 to 11.8 in) depths and depths below $30 \mathrm{~cm}$ to identify the influence of management on surface and subsurface SOC. Changes in SOC due to management treatments were based on initial SOC when it was available for the study or by subtraction from the treatment representing the initial situation (e.g., native prairie, conventional tillage) when SOC was measured at the same time. 


\section{Figure 1}

Agroclimatic zone (ACZ) designations for the Pacific Northwest (adapted from Douglas et al. 1992) and locations of soil carbon studies identified for this study*.

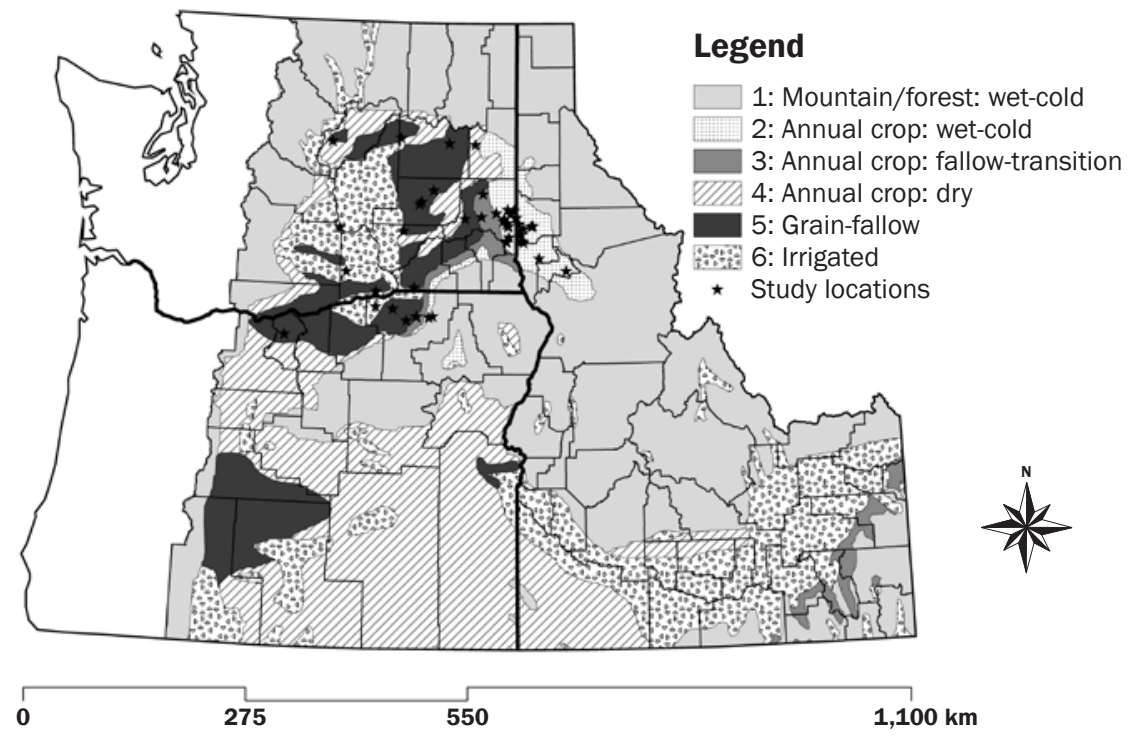

*Although 129 soil organic carbon (SOC) data point locations are represented on the figure, many studies occurred at similar locations and are represented by only one symbol at this scale. Studies appearing in ACZ 6 (irrigated) were not under irrigation management.

Soil profile changes in SOC stocks were estimated based on the SOC depth increment data to characterize the depth-distribution of SOC change for the different management comparisons within an ACZ. For this portion of the analysis, data sets in which SOC was sampled with detailed depth increments were used to empirically model the change in SOC with depth. In all instances, the SOC changes with depth were best described by an exponential relationship, based on coefficient of determination ( $R$-squared) values. The exponential equations of SOC changes with depth fit were used to (1) estimate approximate depths at which no change in SOC occurred, (2) calculate total profile changes in SOC $\left(\mathrm{Mg} \mathrm{C} \mathrm{ha}^{-1}\right)$, and (3) estimate total changes in profile SOC for incomplete datasets that did not include sufficient sampling throughout the soil profile. Data means, standard deviations, and cumulative probability distributions were derived for these profile SOC data (SAS Institute Inc. 2009).

The cumulative probability distributions were developed for the change in profile SOC data for each zone and management comparison. Expected scores of a normally distributed cumulative probability function were based on the number of observations in each management by ACZ dataset. The cumulative distributions of the SOC profile data were then compared to the expected scores for normally distributed data, and from these comparisons, it was concluded that the data were approximately normally distributed. Therefore, changes in SOC due to management practice were interpreted using cumulative probabilities and expected normal scores so that results could be evaluated based on the probability of their occurrence. This assessment allows further quantification of the uncertainty of achieving a particular change in SOC. For example, one could identify an amount of SOC change in which there was a $75 \%$ probability that the data were either equal to or greater than this amount of change. This assessment of uncertainty in SOC change due to a management practice would be useful for policy development and carbon marketing.

\section{Results and Discussion}

The majority of the datasets were located in ACZs 2 and 3, and in many cases, no data was identified for ACZs 1, 4, and 6 (table 1, figure 1). Research quantifying or comparing SOC under different crop rotation and alternative management practices (e.g., burning or use of green manures) for dryland agriculture was limited to just a few studies. The Columbia Basin Agricultural Research Center plots, northeast of Pendleton, Oregon, are the only existing long-term agricultural plots that have evaluated SOC changes under a range of management scenarios for the dryland PNW (Rasmussen and Rohde 1988; Rasmussen and Parton 1994). Long-term research sites located in Lind, Washington; Pullman, Washington; Moscow, Idaho; and Moro, Oregon, were terminated in the 1950s (Horner et al. 1960). These long-term studies, as well as subsequent studies, are not adequate for a comprehensive evaluation of all major current management impacts on soil C sequestration for each ACZ.These data do, however, provide a general understanding of SOC that is important for quantifying SOC stocks and dynamics and in evaluating management systems and practices that favor SOC retention.

Conversion of Native Ecosystems to Agriculture. Annual changes in SOC due to conversion of native vegetation to agriculture ranged from gains of $0.037 \mathrm{Mg} \mathrm{C} \mathrm{ha}{ }^{-1}$ $\mathrm{cm}^{-1} \mathrm{y}^{-1}\left(0.042\right.$ tn $\left.\mathrm{C} \mathrm{ac}^{-1} \mathrm{in}^{-1} \mathrm{yr}^{-1}\right)$ to losses of $0.057 \mathrm{Mg} \mathrm{C} \mathrm{ha}^{-1} \mathrm{~cm}^{-1} \mathrm{y}^{-1}$ (0.065 th C $\left.\mathrm{ac}^{-1} \mathrm{in}^{-1} \mathrm{yr}^{-1}\right)$ measured in the surface 30 $\mathrm{cm}$ (11.8 in) for ACZs 2, 3, and 5 (figure 2). Changes in subsurface SOC were generally less than surface changes and ranged from losses of $0.016 \mathrm{Mg} \mathrm{C} \mathrm{ha}^{-1} \mathrm{~cm}^{-1} \mathrm{y}^{-1}(0.018 \mathrm{tn}$ $\left.\mathrm{C} \mathrm{ac} \mathrm{in}^{-1} \mathrm{yr}^{-1}\right)$ to gains of $0.01 \mathrm{Mg} \mathrm{C} \mathrm{ha}{ }^{-1}$ $\mathrm{cm}^{-1} \mathrm{y}^{-1}\left(0.011\right.$ tn $\left.\mathrm{C} \mathrm{ac}^{-1} \mathrm{in}^{-1} \mathrm{yr}^{-1}\right)$. No clear trend was observed between initial SOC and the annual rate of SOC change (figure 2). Greater initial SOC was generally found in ACZs 2 and 3 than in ACZ 5, primarily due to larger biomass production in dryland ACZs with higher (i.e., ACZs 2 and 3) compared to lower (i.e., ACZ 5) precipitation (Sievers and Holtz 1923). Some cultivated landscape positions maintained or gained SOC following conversion of native perennial vegetation to cropland (figure 2a). This was observed at depths of 20 to $50 \mathrm{~cm}$ (7.9 to $19.7 \mathrm{in}$ ) in three footslope landscape positions in an ACZ 2 study reported by Rodman (1988). This is likely a consequence of soil erosion processes where detached soil organic matter is transported from eroded areas and deposited at lower-lying landscape positions and is consistent with other findings (Busacca et al. 1993; Montgomery et al. 1997). These data illustrate the importance of considering landscape position in addition to management history when studying changes in SOC. Quantifying this contribution to the SOC balance would be appropriate for determining the net $\mathrm{C}$ sequestration potential across the landscape 


\section{Figure 2}

Changes in soil organic carbon (SOC) following conversion of native vegetation to agriculture in each agroclimatic zone (ACZ) by (a) initial SOC and (b) study time period. Figure $2 \mathrm{~b}$ includes all depth increments for the respective agroclimatic zone.

(a)

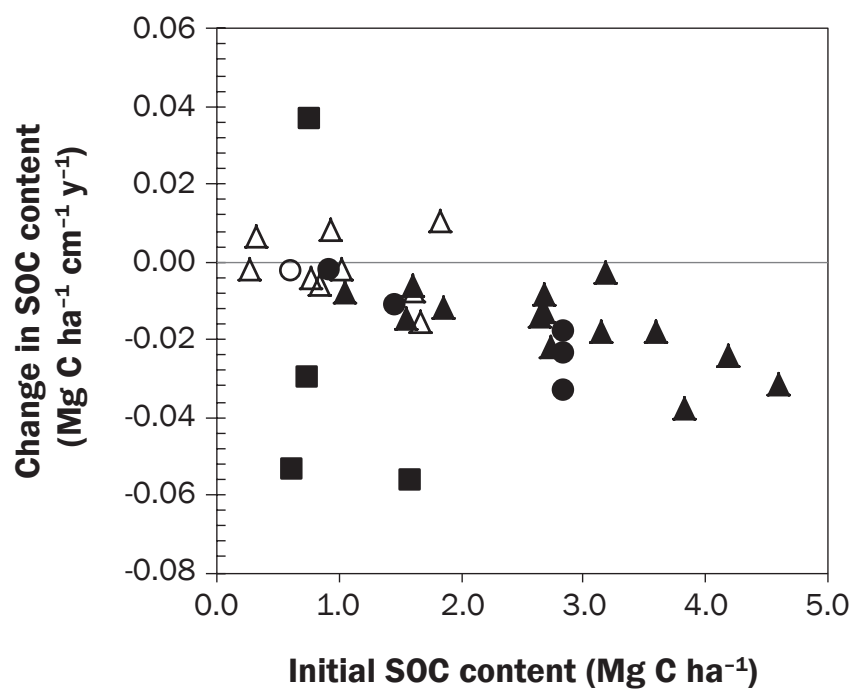

Legend

$\Delta$ ACZ2, 0 to $30 \mathrm{~cm}$

- ACZ3, 0 to $30 \mathrm{~cm}$

ACZ5, surface $15 \mathrm{~cm}$

$\triangle \mathrm{ACZ2}$, below $30 \mathrm{~cm}$

O ACZ3, below $30 \mathrm{~cm}$ (b)

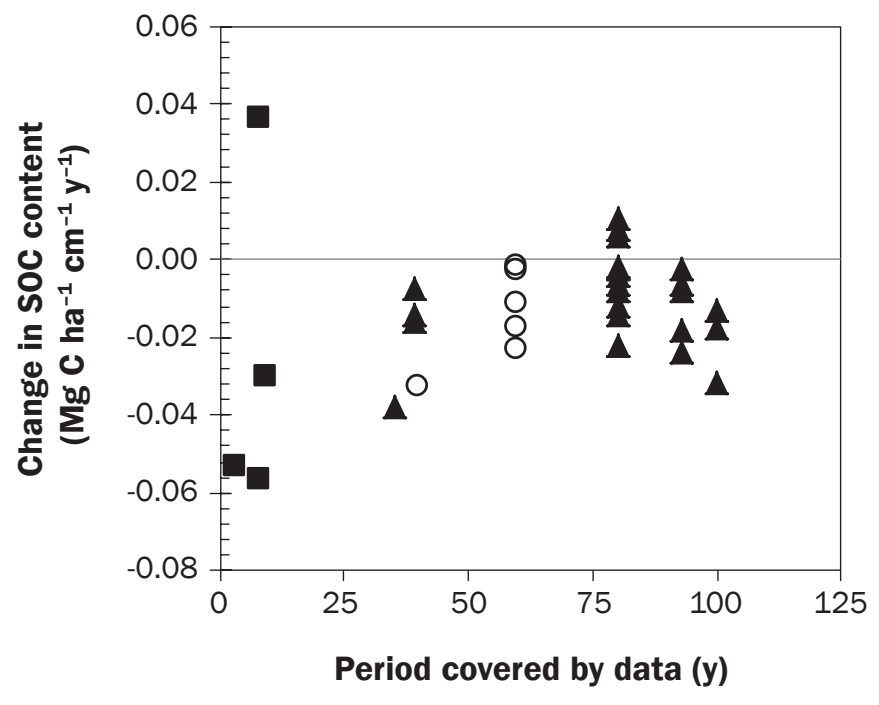

Legend

$\triangle \mathrm{ACZ2} O \mathrm{ACZ3} \quad \mathrm{ACZ} 5$

\section{Figure 3}

Changes in soil organic carbon (SOC) with depth following conversion of native vegetation to cropland by agroclimatic zone (ACZ). The L indicates data points from lowland landscape positions, and all others were (or assumed to be if not reported) from upland landscape positions.

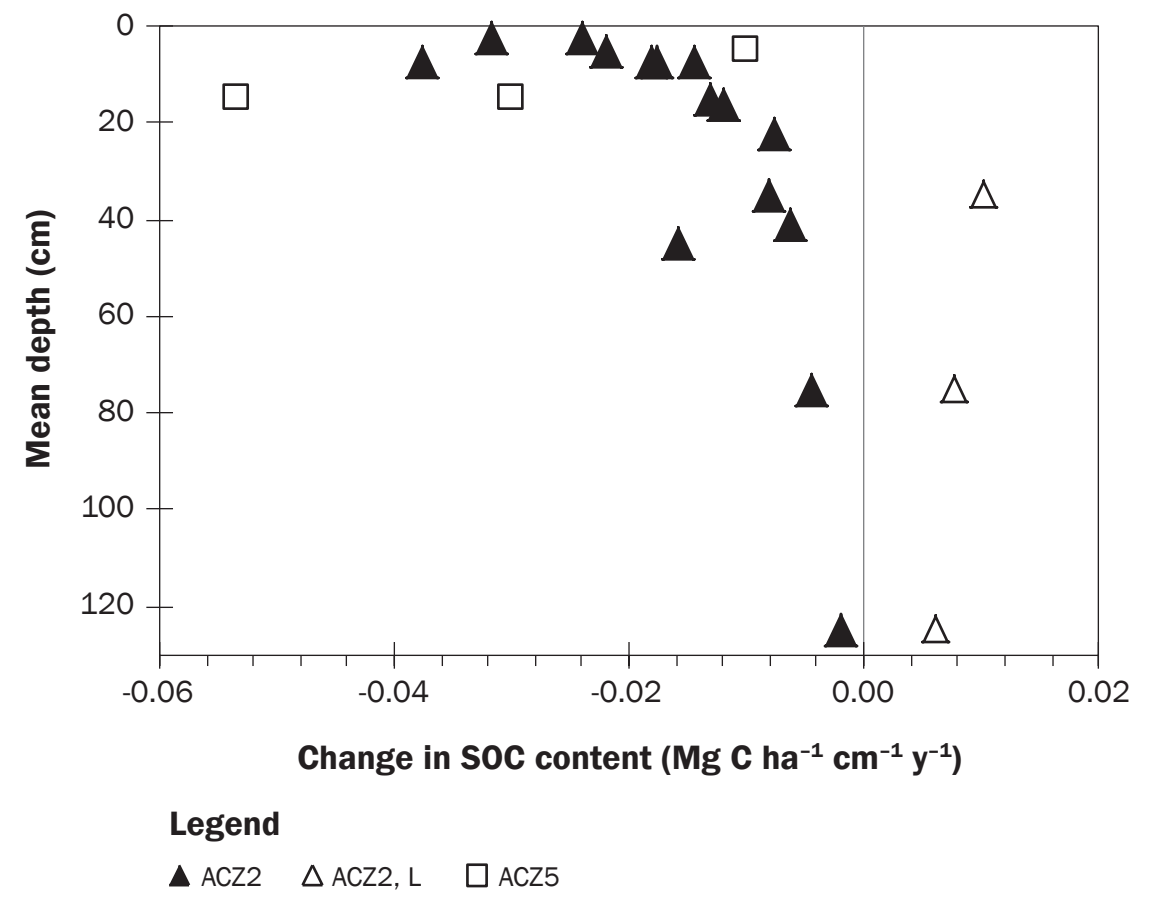

(VandenBygaart et al. 2002); however, little is currently known about the fate of soil $\mathrm{C}$ that is transported from the field via soil erosion processes, particularly with respect to greenhouse gas emissions.

In ACZ 5, the mean rates of change and standard deviation were relatively high compared to ACZs 2 and 3 (figure 3). This is likely a consequence of the relatively large ranges in duration of cultivation (from three years to decades) as well as differences in cultivation management for the ACZ 5 studies. Greater variability would be expected for these data as the rate of SOC change tends to proceed more rapidly during the initial years of cultivation or following a management change (West and Post 2002). Schillinger et al. (2007) reported gains and losses of SOC as compared to native levels in ACZ 5 where SOC decreased by $0.057 \mathrm{Mg} \mathrm{C} \mathrm{ha-1} \mathrm{cm}^{-1} \mathrm{y}^{-1}(0.065$ tn $\left.\mathrm{C} \mathrm{ac}^{-1} \mathrm{in}^{-1} \mathrm{yr}^{-1}\right)$ in the surface $5 \mathrm{~cm}$ (2 in) but increased by $0.037 \mathrm{Mg} \mathrm{C}$ ha $\mathrm{cm}^{-1} \mathrm{y}^{-1}$ (0.042 $\left.\mathrm{tn} \mathrm{C} \mathrm{ac}^{-1} \mathrm{in}^{-1} \mathrm{yr}^{-1}\right)$ at the 5 to $10 \mathrm{~cm}$ (2 to $3.9 \mathrm{in}$ ) depth (figure 2). Here, the elevated SOC in the subsurface under cultivation was attributed to decades of residue burial when the site was in a winter wheat-fallow rotation.

Following conversion of native vegetation to cultivation-based agriculture, profile SOC 
Table 2

Summary of profile changes in soil organic carbon (SOC) calculated from the mean and cumulative probability function for native conversion, adoption of no-tillage management, and use of a mixed perennial-annual rotation.

\begin{tabular}{|c|c|c|c|c|c|c|c|}
\hline \multirow[b]{2}{*}{ Management } & \multirow[b]{2}{*}{$\mathrm{ACZ}$} & \multirow{2}{*}{$\begin{array}{l}\text { Number } \\
\text { of studies }\end{array}$} & \multirow{2}{*}{$\begin{array}{l}\text { Period covered } \\
\text { by data } \\
\text { (mean y) }\end{array}$} & \multirow{2}{*}{$\begin{array}{l}\text { Mean Soc } \\
\text { change } † \\
\left(\mathrm{Mg} \mathrm{C} \mathrm{ha}^{-1} \mathrm{y}^{-1}\right)\end{array}$} & \multicolumn{3}{|c|}{$\begin{array}{l}\text { Cumulative probability estimate of } \\
\text { SOC change }{ }^{*}\left(\mathrm{Mg} \mathrm{C} \mathrm{ha-1}^{-1}\right)\end{array}$} \\
\hline & & & & & 25th & 50th & 75th \\
\hline \multicolumn{8}{|c|}{ Native conversion } \\
\hline & 2 & 7 & 74 & $-0.84( \pm 0.17)$ & -0.70 & -0.82 & -0.92 \\
\hline & 3 & 4 & 55 & $-0.53( \pm 0.18)$ & -0.35 & -0.48 & -0.58 \\
\hline & 5 & 3 & 7 & $-0.69( \pm 0.52)$ & -0.14 & -0.47 & -0.80 \\
\hline \multicolumn{8}{|l|}{ No-tillage } \\
\hline & 2 & 12 & 14 & $0.71( \pm 0.63)$ & 0.21 & 0.64 & 1.04 \\
\hline & 3 & 5 & 10 & $0.21( \pm 0.10)$ & 0.12 & 0.19 & 0.25 \\
\hline \multicolumn{8}{|c|}{ Mixed perennial-annual } \\
\hline & 2 & 8 & 12 & $1.03( \pm 0.41)$ & 0.69 & 0.94 & 1.12 \\
\hline
\end{tabular}

Note: $\mathrm{ACZ}=$ agroclimatic zone.

* The 25th, 50th, and 75th percentiles of the cumulative probability function.

† Values in parenthesis indicate plus or minus one standard deviation from the mean value.

declined an average of $0.84 \pm 0.17 \mathrm{Mg} \mathrm{C}$ $\mathrm{ha}^{-1} \mathrm{y}^{-1}\left(0.38 \pm 0.08\right.$ tn $\left.\mathrm{C} \mathrm{ac}^{-1} \mathrm{yr}^{-1}\right)$ in ACZ 2, while losses were less in ACZ $3(0.53 \pm 0.18$ $\mathrm{Mg} \mathrm{C} \mathrm{ha} \mathrm{y}^{-1}\left[0.24 \pm 0.08\right.$ tn $\left.\left.\mathrm{C} \mathrm{ac} \mathrm{yr}^{-1}\right]\right)$ and ACZ $5\left(0.69 \pm 0.52 \mathrm{Mg} \mathrm{ha}^{-1} \mathrm{y}^{-1}[0.31 \pm\right.$ 0.23 tn $\mathrm{C} \mathrm{ac}^{-1} \mathrm{yr}^{-1}$ ) (table 2). About $50 \%$ of the SOC loss occurred in the surface $30 \mathrm{~cm}$ (11.8 in) depth of the soil profile assessed for ACZ 2, while $50 \%$ of the SOC loss occurred in the surface $13 \mathrm{~cm}$ (5.1 in) in ACZ 3 (figure 3). These data reflect differences in biomass production due to climatic factors as well as management differences between ACZs 2 and 3.

These estimates of SOC losses following conversion of native land to dryland agriculture represent 15 data sets with an average of up to 74 years of cropping history (table 2). Although sites that have been under cultivation for a longer period of time may show greater overall SOC loss, more recently converted soils will likely have greater initial rates of SOC loss until a new steady-state is approached (Huggins et al. 1998). Sievers and Holtz (1922) reported a 34.5\% decrease in SOC, relative to initial SOC, within the surface $60 \mathrm{~cm}$ (23.6 in) after 39 years of cropping near Pullman, Washington. These soils may have been approaching a new steady state where detectable SOC changes would only be expected with further management changes.

Means of SOC change had large standard deviations likely due to the influence of soil erosion, sampling errors, and other factors contributing to field SOC variability, and it was considered valuable to express SOC changes on a cumulative probability basis (figure 4, table 2). These analyses showed that $75 \%$ of the converted native ecosystems were expected to have lost at least $0.7 \mathrm{Mg} \mathrm{C} \mathrm{ha}{ }^{-1}$ $\mathrm{y}^{-1}\left(0.31 \mathrm{tn}^{\mathrm{C} \mathrm{ac}} \mathrm{yr}^{-1}\right)$ or 2.57 metric tons carbon dioxide equivalents per hectare per year $\left(\mathrm{MtCO}_{2}\right.$ e ha $\left.\mathrm{y}^{-1}\right)$, a common $\mathrm{C}$ trading unit, over 74 years in ACZ 2. In ACZ 3 , a SOC loss of at least $0.35 \mathrm{MgC} \mathrm{ha}^{-1} \mathrm{y}^{-1}$ (0.16 tn $\mathrm{C} \mathrm{ac}^{-1} \mathrm{yr}^{-1}$ ) or 1.28 $\mathrm{MtCO}_{2} \mathrm{e} \mathrm{ha}^{-1}$ $\mathrm{y}^{-1}$ over 55 years would be expected on $75 \%$ of converted sites. Soil organic C losses of $0.14 \mathrm{Mg} \mathrm{C} \mathrm{ha}^{-1} \mathrm{y}^{-1}\left(0.06\right.$ tn $\left.\mathrm{C} \mathrm{ac} \mathrm{yr}^{-1}\right)$ or $0.51 \mathrm{MtCO}_{2} \mathrm{e} \mathrm{ha}^{-1} \mathrm{y}^{-1}$ or more over 7 years would be expected on $75 \%$ of ACZ 5 sites. Using these results and methodology, the degree of uncertainty in SOC changes due to management can be incorporated into land management, $\mathrm{C}$ marketing, and green house gas mitigation policy scenarios.

Conversion from Conventional Tillage to No-Tillage. Conversion from CT to NT generally resulted in positive rates of SOC gain for the surface $30 \mathrm{~cm}$ (11.8 in) (figure 5). Surface $30 \mathrm{~cm}$ changes in SOC following adoption of $\mathrm{NT}$ ranged from a gain of 0.21 $\mathrm{Mg} \mathrm{C} \mathrm{ha}{ }^{-1} \mathrm{~cm}^{-1} \mathrm{y}^{-1}\left(0.24\right.$ tn $\mathrm{C} \mathrm{ac}{ }^{-1}$ in $\left.^{-1} \mathrm{yr}^{-1}\right)$ to a loss of $0.20 \mathrm{Mg} \mathrm{C} \mathrm{ha}^{-1} \mathrm{~cm}^{-1} \mathrm{y}^{-1}(0.23 \mathrm{tn}$ $\mathrm{C} \mathrm{ac}^{-1} \mathrm{in}^{-1} \mathrm{yr}^{-1}$ ) (figure 5). Changes in SOC were not related to initial SOC content; however, the rate of SOC change tended to decrease after the initial 10 years of conversion (figure 5a). Data for SOC in ACZs 2, 3 , and 5 usually were from the surface 10 to $20 \mathrm{~cm}$ (3.9 to $7.9 \mathrm{in})$, largely ignoring the potential impact of management on profile SOC. In a few instances, NT was reported to have less SOC than the CT counterpart
(Fuentes et al. 2004; Granatstein et al. 1987). Fuentes et al. (2004) noted a $0.017 \mathrm{Mg} \mathrm{ha}^{-1}$ $\mathrm{cm}^{-1} \mathrm{y}^{-1}$ (0.019 th $\mathrm{C} \mathrm{ac}{ }^{-1} \mathrm{in}^{-1} \mathrm{yr}^{-1}$ ) SOC increase at 0 to $5 \mathrm{~cm}$ ( 0 to 2 in) but a 0.004 $\mathrm{Mg} \mathrm{ha} \mathrm{cm}^{-1} \mathrm{y}^{-1}$ (0.005 tn $\mathrm{C} \mathrm{ac} \mathrm{Cin}^{-1} \mathrm{yr}^{-1}$ ) decrease at 5 to $10 \mathrm{~cm}$ (2 to 3.9 in) after 27 years under NT as compared to CT.This distribution of SOC change may be explained by residue burial at the plow depth under CT that is absent in a NT system.

Adoption of NT following CT generally resulted in SOC increases with 58\% or more of the SOC change captured in the surface $5 \mathrm{~cm}$ (2 in) and declining with depth to near zero at $20 \mathrm{~cm}$ (7.9 in) (data not shown). In ACZ 2, profile SOC stocks increased on average by $0.71 \pm 0.63 \mathrm{Mg} \mathrm{C}$ $\mathrm{ha}^{-1} \mathrm{y}^{-1}\left(0.32 \pm 0.28\right.$ tn $\left.\mathrm{C} \mathrm{ac} \mathrm{yr}^{-1}\right)$ over an average of 14 years following conversion of CT to NT (table 2). All changes in profile SOC for ACZ 2 occurred within the surface $20 \mathrm{~cm}$. Soil profile organic $\mathrm{C}$ increases were less in ACZ 3, averaging $0.21 \pm 0.10 \mathrm{Mg} \mathrm{C}$ $\mathrm{ha}^{-1} \mathrm{y}^{-1}\left(0.09 \pm 0.04\right.$ tn $\left.\mathrm{C} \mathrm{ac}^{-1} \mathrm{yr}^{-1}\right)$ in the surface $20 \mathrm{~cm}$ over an average of 10 years following conversion. Given the relatively high standard deviations for these data, the cumulative probability analyses were again useful for further defining expectations for SOC changes (figure $4 b$ ). From the cumulative probability analysis, it was predicted that $75 \%$ of ACZ 2 conversions from CT to NT would increase SOC at a rate of at least 0.21 $\mathrm{Mg} \mathrm{C} \mathrm{ha} \mathrm{y}^{-1}\left(0.09\right.$ tn $\left.\mathrm{C} \mathrm{ac}^{-1} \mathrm{yr}^{-1}\right)$ or 0.77 $\mathrm{MtCO}_{2} \mathrm{e} \mathrm{ha}^{-1} \mathrm{y}^{-1}$ during the initial 14 years (table 2). Similarly for ACZ 3 , increases of at least $0.12 \mathrm{MgC} \mathrm{ha}^{-1} \mathrm{y}^{-1}\left(0.05\right.$ tn $\left.\mathrm{C} \mathrm{ac}^{-1} \mathrm{yr}^{-1}\right)$ 


\section{Figure 4}

Cumulative probability plots for change in soil organic carbon (SOC) following (a) conversion of native vegetation to cropland and (b) conversion from conventional tillage (CT) to no-tillage (NT). Symbols are observed values, and lines represent the expected normal scores.

(a)

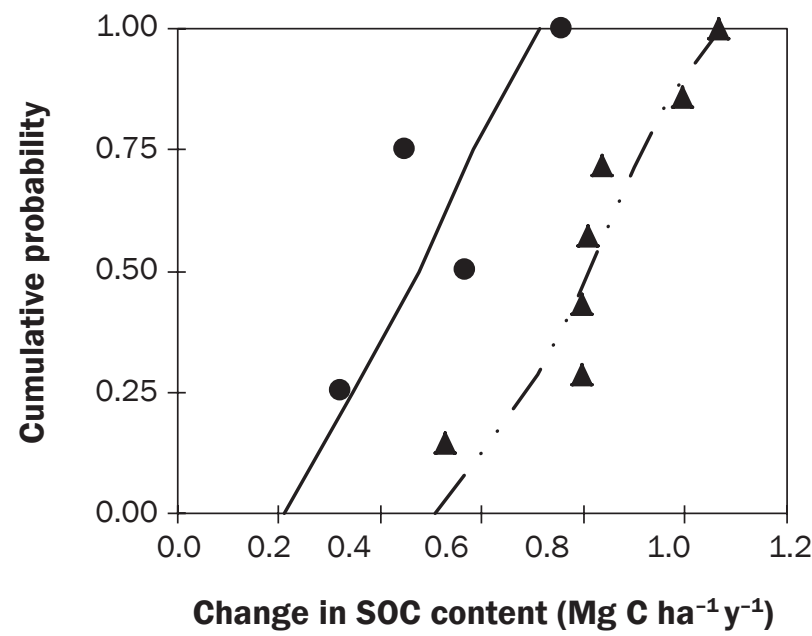

Legend

$\triangle \mathrm{ACZ2}$

- ACZ3 (b)

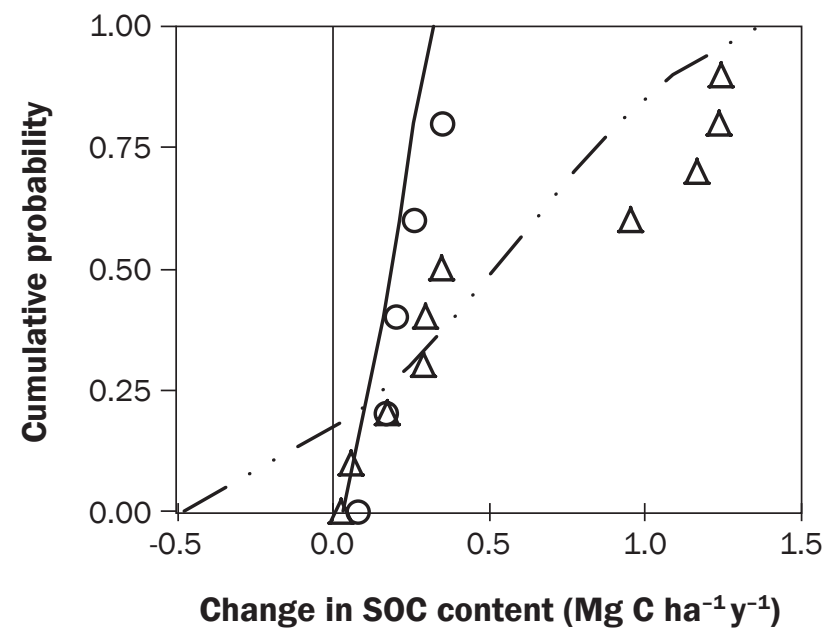

Legend
$\triangle \mathrm{ACZ2}$
ACZ2
○ ACZ3
ACZ3

or $0.44 \mathrm{MtCO}_{2} \mathrm{e} \mathrm{ha}^{-1} \mathrm{y}^{-1}$ would be expected less than $0.07 \mathrm{Mg} \mathrm{C} \mathrm{ha}^{-1} \mathrm{y}^{-1}(0.03$ tn $\mathrm{C} \mathrm{ac}$ during the first 10 years for $75 \%$ of sites. $\mathrm{yr}^{-1}$ ) or $0.26 \mathrm{MtCO}_{2} \mathrm{e} \mathrm{ha}^{-1} \mathrm{y}^{-1}$ with no appreAlthough insufficient numbers of studies ciable gain in SOC below $5 \mathrm{~cm}$ following 14 occurred for this kind of analysis in ACZ 5, years of NT (Bezdicek et al. 1998).

SOC was observed to accumulate at a rate of
The 0.21 to $0.71 \mathrm{Mg} \mathrm{C} \mathrm{ha}^{-1} \mathrm{y}^{-1}$ (0.09 to 0.32 tn $\mathrm{C} \mathrm{ac}^{-1} \mathrm{yr}^{-1}$ ) sequestration estimate averages for ACZs 2 and 3, respectively, are at the extreme ends of the global range $(0.3$ to $0.8 \mathrm{Mg} \mathrm{C} \mathrm{ha} \mathrm{y}^{-1}\left[0.13\right.$ to 0.36 tn $\mathrm{ac}^{-1}$

\section{Figure 5}

Change in soil organic carbon with shift from conventional tillage (CT) to no-tillage (NT) versus (a) initial SOC and (b) study time period.

(a)

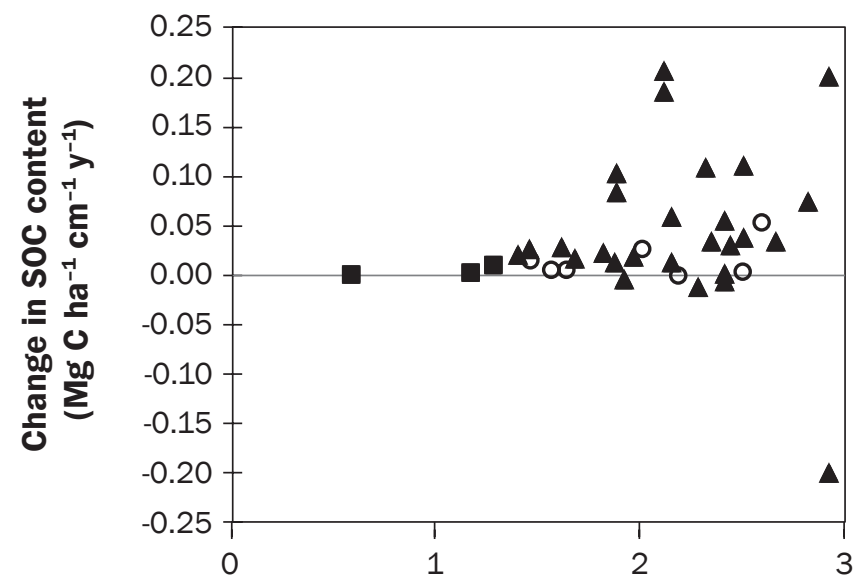

Initial SOC content (Mg C ha-1) (b)

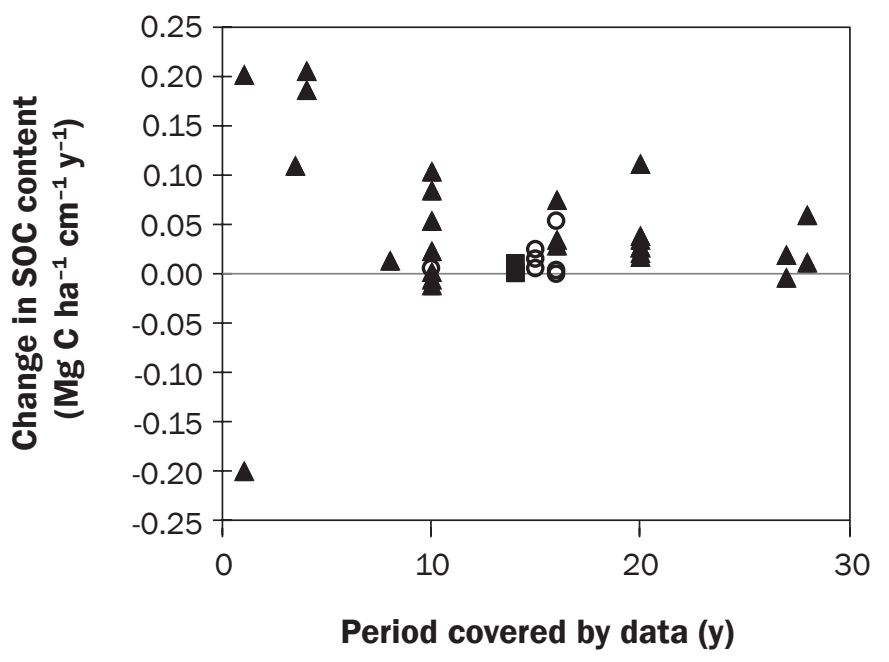

Legend

A ACZ2 O ACZ3 $\quad$ ACZ5 
$\mathrm{yr}^{-1}$ ]) reported by Smith (2004) for improved management practices. The ACZ 2 rate of SOC change $\left(0.71 \mathrm{Mg} \mathrm{C} \mathrm{ha} \mathrm{y}^{-1}[0.32\right.$ tn $\left.\left.\mathrm{C} \mathrm{ac}^{-1} \mathrm{yr}^{-1}\right]\right)$ exceeds the upper limit of the 0.3 to $0.6 \mathrm{Mg} \mathrm{C} \mathrm{ha}^{-1} \mathrm{y}^{-1}$ (0.13 to 0.27 tn $\mathrm{ac}^{-1} \mathrm{yr}^{-1}$ ) used by Follett (2001) for NT adoption on CT cropland. The ACZ 2 SOC sequestration rate is also higher than the surface $30 \mathrm{~cm}$ (11.8 in) rate increase $(0.57$ $\pm 0.14 \mathrm{C} \mathrm{Mg} \mathrm{ha}^{-1} \mathrm{y}^{-1}[0.25$ to 0.06 tn $\mathrm{C}$ $\left.\mathrm{ac}^{-1} \mathrm{yr}^{-1}\right]$ ) reported by West and Post (2002) and the $0.5 \mathrm{Mg} \mathrm{C} \mathrm{ha}^{-1} \mathrm{y}^{-1}\left(0.22 \mathrm{tn} \mathrm{C} \mathrm{ac}^{-1}\right.$ $\mathrm{yr}^{-1}$ ) estimate for the surface $20 \mathrm{~cm}$ (7.9 in) reported by Lal et al. (1998) in a global and national analysis, respectively, of NT compared to CT. Furthermore, the ACZ 2 value is much higher than the $0.23 \mathrm{Mg} \mathrm{C} \mathrm{ha}^{-1} \mathrm{y}^{-1}$ (0.10 tn $\left.\mathrm{C} \mathrm{ac}^{-1} \mathrm{yr}^{-1}\right)$ reported by Paustian et al. (1997) and the $0.3 \mathrm{Mg} \mathrm{C} \mathrm{ha}^{-1} \mathrm{y}^{-1}(0.13 \mathrm{tn}$ $\mathrm{C} \mathrm{ac}^{-1} \mathrm{yr}^{-1}$ ) estimated by West and Marland (2001), comparing NT to CT sites nationally. In contrast, the $0.21 \mathrm{Mg} \mathrm{C} \mathrm{ha}^{-1} \mathrm{y}^{-1}(0.09$

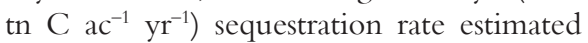
for conversion from CT to NT in ACZ 3 is similar to lower rates reported (Paustian et al. 1997; Follett 2001; West and Marland 2001; Smith 2004; Liebig et al. 2005). Factors that could contribute to the relatively high rates of SOC change reported as well as the large range and standard deviation include soil sampling biases and the influence of soil erosion. Sampling biases can arise if soil sampling occurs soon after a recent addition of biomass from residues, for example after harvest when it is logistically more feasible to conduct sampling operations. Here, residues and root sources of $\mathrm{C}$ can become mixed with the sample and difficult to remove prior to total "soil" C analysis. The significance of this sampling issue increases with greater crop yields and associated residue and root inputs. High yielding areas in ACZ 2 can result in carbon loads in aboveground crop residues of 4.5 $\mathrm{Mg} \mathrm{C} \mathrm{ha}^{-1}$ (2 tn $\mathrm{C} \mathrm{ac}^{-1}$ ) (Huggins and Kruger 2010). Even the inclusion of a small proportion of this residue $\mathrm{C}$ in soil samples would result in significant sample-related errors in SOC change estimates. These data indicate that SOC sampling should take place prior to significant $\mathrm{C}$ inputs from the current crop, for example in the late spring to summer time period. In addition, field variability of profile SOC can be increased as a result of long-term soil erosion processes that redistribute SOC within the landscape (Busacca et al. 1985). High soil erosion rates in the dryland PNW have been attributed to steep slopes and historical farm practices. One or two percent SOC and an annual erosion rate of $25 \mathrm{Mg}$ soil ha ${ }^{-1}\left(11 \mathrm{tn} \mathrm{C} \mathrm{ac}^{-1}\right)$ could result in 0.25 to $0.5 \mathrm{Mg} \mathrm{C} \mathrm{ha}^{-1} \mathrm{y}^{-1}$ (0.11 to 0.22 tn $\left.\mathrm{C} \mathrm{ac}^{-1} \mathrm{yr}^{-1}\right)$ to be either lost from eroded landscape positions or gained in depositional landscape positions. Therefore, the change in SOC that is measured through soil sampling at a given location includes contributions of $\mathrm{C}$ inputs and losses from both soil erosion and biological processes. At this time, only biological processes are directly linked to greenhouse gas production or mitigation by soil. Long-term soil erosion effects on SOC field redistribution can result in large errors in assessing management-induced changes in SOC in studies that lack initial baseline data. Here, paired-farm or field samples are often collected from limited field areas at the same time, and differences in SOC can be attributed to the relatively recent change in management. In these cases, landscape-scale soil erosion processes could have differentially influenced initial SOC as well as affected soil $\mathrm{C}$ gains and losses at the sampled location during the study period thereby introducing considerable error in estimated SOC changes. Under these circumstances, evaluation of representative landscapes is required to assess management-induced changes in SOC over time (VandenBygaart et al. 2002).

Conversion of Conventional Tillage to Reduced Tillage. In ACZs 2 and 3, one and four data sets addressing changes in SOC with adoption of reduced tillage (RT) were identified, respectively. In ACZ 2, use of RT resulted in a $0.045 \mathrm{Mg} \mathrm{C} \mathrm{ha}^{-1} \mathrm{y}^{-1}(0.02 \mathrm{tn}$ $\mathrm{C} \mathrm{ac}^{-1} \mathrm{yr}^{-1}$ ) or $0.17 \mathrm{MtCO}_{2} \mathrm{e} \mathrm{ha}^{-1} \mathrm{y}^{-1} \mathrm{SOC}$ increase in the surface $15 \mathrm{~cm}$ (5.9 in) compared to CT. In ACZ 3, RT resulted in a relatively large increase of SOC in the surface $7.5 \mathrm{~cm}$ ( $3 \mathrm{in})$ that declined to near zero between 7.5 to $22.5 \mathrm{~cm}$ (3 to $8.9 \mathrm{in}$ ). In contrast to CT conversion to NT, the SOC changes from RT increased at 22.5 to $45 \mathrm{~cm}$ (8.9 to 17.7 in) depths, indicating that RT may be more efficient at increasing SOC in the subsoil as compared to NT.

\section{Mixed Perennial-Annual Cropping} Systems. The inclusion of a perennial crop into an otherwise annual crop rotation (mixed perennial-annual rotation) resulted in gains, losses, and maintenance of SOC measured within the surface $30 \mathrm{~cm}$ (11.8 in) of soils in ACZs 2 and 3 (figure 6). In ACZ 2 , SOC increases were up to $0.066 \mathrm{Mg} \mathrm{C}$ $\mathrm{ha}^{-1} \mathrm{~cm}^{-1} \mathrm{y}^{-1}\left(0.075\right.$ tn $\left.\mathrm{C} \mathrm{ac} \mathrm{in}^{-1} \mathrm{yr}^{-1}\right)$ while losses were as high as $0.009 \mathrm{Mg} \mathrm{C} \mathrm{ha}^{-1} \mathrm{~cm}^{-1}$ $\mathrm{y}^{-1}\left(0.010\right.$ tn $\left.\mathrm{C} \mathrm{ac}^{-1} \mathrm{in}^{-1} \mathrm{yr}^{-1}\right)$. There were no clear trends between changes in SOC and length of time (data not shown) or proportion of the mixed perennial-annual rotation in a perennial crop (figure 6b). In ACZ 3, a SOC decrease of $0.03 \mathrm{Mg} \mathrm{C} \mathrm{ha} \mathrm{cm}^{-1} \mathrm{y}^{-1}$ (0.034 tn $\mathrm{C} \mathrm{ac}^{-1} \mathrm{in}^{-1} \mathrm{yr}^{-1}$ ) was reported by Horner et al. (1960) in a 6-year rotation that included 3 years of alfalfa.

Compared to annual cropping systems, mixed perennial-annual systems increased mean SOC stocks in the soil profile by 1.03 $\pm 0.41 \mathrm{Mg} \mathrm{Cha} \mathrm{y}^{-1}\left(0.46 \pm 0.18\right.$ tn $\mathrm{C} \mathrm{ac}^{-1}$ $\mathrm{yr}^{-1}$ ) (table 2). The value obtained in this analysis is higher than the $0.33 \mathrm{Mg} \mathrm{C} \mathrm{ha}{ }^{-1}$ $\mathrm{y}^{-1}\left(0.15\right.$ tn $\left.\mathrm{C} \mathrm{ac} \mathrm{yr}^{-1}\right)$ global estimate for converting agricultural land back to grassland vegetation reported by Post and Kwon (2000) and also higher than the $0.94 \pm 0.86$ $\mathrm{Mg} \mathrm{C} \mathrm{ha} \mathrm{y}^{-1} \mathrm{y}^{-1}\left(0.42 \pm 0.38\right.$ tn $\left.\mathrm{C} \mathrm{ac} \mathrm{yr}^{-1}\right)$ regional rate reported by Liebig et al. (2005) for conversion of cropland or reclaimed mining land to grass. Again, considering the high standard deviations associated with these data, the cumulative probability analyses provided a more conservative estimate of SOC gains. This analysis indicates that $75 \%$ of ACZ 2 sites adopting a mixed perennial-annual rotation would be expected to increase SOC at a rate of at least $0.69 \mathrm{Mg} \mathrm{C} \mathrm{ha-1} \mathrm{y}^{-1}(0.31 \mathrm{tn}$ $\mathrm{C} \mathrm{ac}^{-1} \mathrm{yr}^{-1}$ ) or $2.53 \mathrm{MtCO}_{2} \mathrm{e} \mathrm{ha}^{-1} \mathrm{y}^{-1}$ over a 12-year period (table 2).

Conservation Reserve Program Plantings. The Conservation Reserve Program (CRP) is a voluntary US Farm Bill program of the USDA that encourages farmers to convert highly erodible cropland or other environmentally sensitive acreage to conservation vegetation, such as introduced or native grasses, trees, filter strips, or riparian buffers. Most contracts are originally signed for 10 years though extensions may be granted. No data were found that evaluated CRP planting effects on SOC changes for ACZs 1, 4, and 6. In ACZ 2, Purakayastha et al. (2008) noted a SOC gain of 0.07 and $0.005 \mathrm{Mg} \mathrm{C} \mathrm{ha}^{-1} \mathrm{~cm}^{-1}$ $\mathrm{y}^{-1}\left(0.08\right.$ and 0.006 tn $\mathrm{C} \mathrm{ac}^{-1}$ in $\left.^{-1} \mathrm{yr}^{-1}\right)$ at 0 to $5 \mathrm{~cm}$ (0 to $2 \mathrm{in}$ ) and 5 to $10 \mathrm{~cm} \mathrm{(2} \mathrm{to} 3.9$ in), respectively, after 11 years in the CRP. In a study of 20 Washington soils, an average $0.024 \mathrm{Mg} \mathrm{C} \mathrm{ha} \mathrm{cm}^{-1} \mathrm{y}^{-1} \quad\left(0.027 \mathrm{tn} \mathrm{C} \mathrm{ac}^{-1}\right.$ $\mathrm{in}^{-1} \mathrm{yr}^{-1}$ ) gain in SOC was reported after 4.5 to 5.5 years in CRP plantings (Karlen et al. 1999). If these SOC gains were representative to a $20 \mathrm{~cm}$ (7.9 in) soil depth, then about 0.48 $\mathrm{Mg} \mathrm{C} \mathrm{ha} \mathrm{y}^{-1}\left(0.21\right.$ tn $\left.\mathrm{C} \mathrm{ac}^{-1} \mathrm{yr}^{-1}\right)$ would be 


\section{Figure 6}

Influence of mixed perennial-annual crop rotations on soil organic carbon (SOC) in agroclimatic zones (ACZ) 2 and 3 versus (a) initial SOC and (b) proportion of rotation under perennial cropping.

(a)

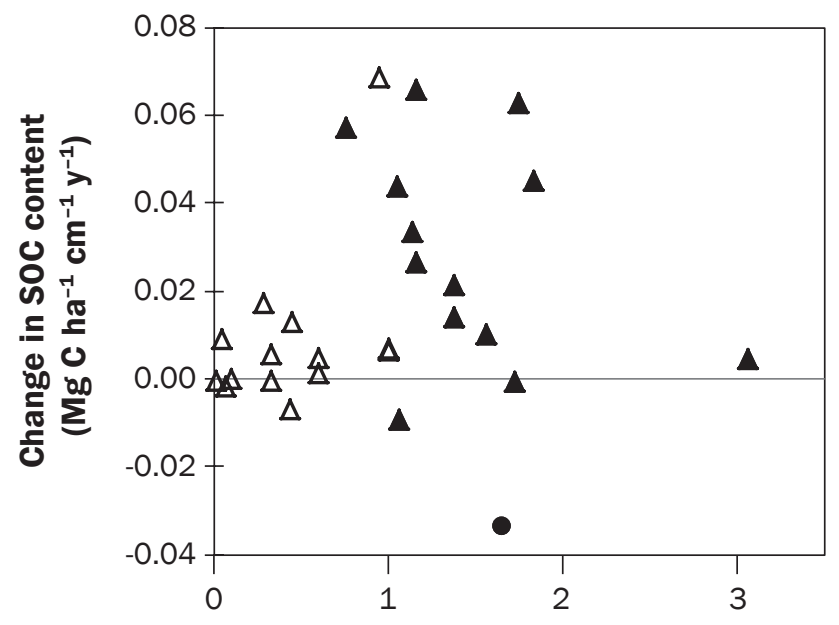

Initial SOC content (Mg C ha-1) (b)

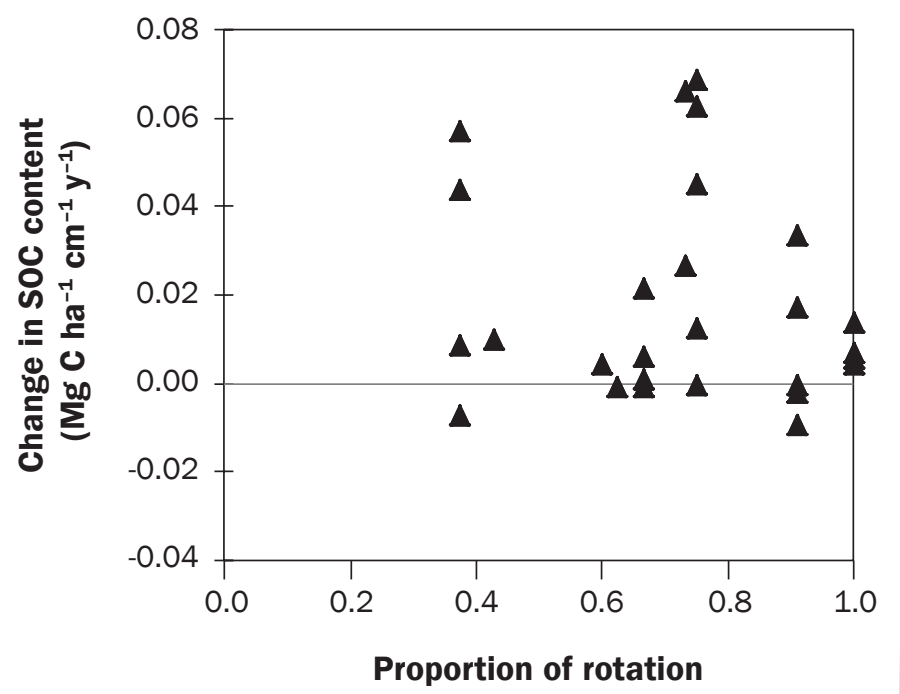

ACZ3, 0 to $30 \mathrm{~cm}$ expected, a rate that is over two times greater than the $0.2 \mathrm{Mg} \mathrm{C} \mathrm{ha}^{-1} \mathrm{y}^{-1}\left(0.09\right.$ tn $\mathrm{C} \mathrm{ac}^{-1}$ $\mathrm{yr}^{-1}$ ) value used by Cook (2007) but only about $50 \%$ of the $0.94 \pm 0.86 \mathrm{Mg} \mathrm{C} \mathrm{ha}^{-1}$ $\mathrm{y}^{-1}\left(0.42 \pm 0.38\right.$ tn $\left.\mathrm{C} \mathrm{ac}^{-1} \mathrm{y}^{-1}\right)$ estimated by Liebig et al. (2005) for conversion of cropland to grass. Furthermore, Sanchez de-Leon (2007) observed that changes in SOC under CRP remained $0.11,0.18$, and $0.15 \mathrm{Mg} \mathrm{C}$ $\mathrm{ha}^{-1} \mathrm{y}^{-1}\left(0.05,0.08\right.$, and 0.07 tn $\left.\mathrm{C} \mathrm{ac} \mathrm{yr}^{-1}\right)$ below those of native Palouse prairie for the 0 to 10 (0 to 3.9$), 10$ to 20 (3.9 to 7.9 ), and 20 to $30 \mathrm{~cm}$ (7.9 to $11.8 \mathrm{in})$ depth increments, respectively, after approximately 23 years in CRP conservation cover.

Crop Residue Burning. Burning resulted in a loss of $0.03 \mathrm{Mg} \mathrm{C} \mathrm{ha}^{-1} \mathrm{~cm}^{-1} \mathrm{y}^{-1}(0.034 \mathrm{th}$ $\left.\mathrm{C} \mathrm{ac}{ }^{-1} \mathrm{in}^{-1} \mathrm{yr}^{-1}\right)$ within the surface $15 \mathrm{~cm}(5.9$ in) for a soil in ACZ 2 (Horner et al. 1960). The SOC also declined, however, under cropland management in which residue was not burned, but here the rate of SOC loss was reduced by approximately $0.01 \mathrm{Mg} \mathrm{C} \mathrm{ha}{ }^{-1}$ $\mathrm{cm}^{-1} \mathrm{y}^{-1}$ (0.011 tn $\mathrm{C} \mathrm{ac}^{-1} \mathrm{in}^{-1} \mathrm{yr}^{-1}$ ) (Horner et al. 1960). In ACZ 3, Rasmussen and Parton (1994) reported a close to $50 \%$ reduction in SOC losses in the surface $30 \mathrm{~cm}$ (11.8 in) from not burning crop residue compared to crop residue burning over 55 years. Horner et al. (1960) showed similar SOC losses for both burned and nonburned treatments in
ACZ 3 after 10 years of residue burning. The difference between the rate of SOC decline reported by Horner et al. (1960) and Rasmussen and Parton (1994) is likely due to the different lengths of time under burning management and depth of soil sampling (30 versus $20 \mathrm{~cm}$ [11.8 versus $7.9 \mathrm{in}$ ] for Horner et al. [1960] and Rasmussen and Parton [1994], respectively).

Barnyard and Green Manures. In studies from ACZ 2, SOC changes following addition of barnyard manure ranged from slight declines $\left(-0.005\right.$ to $-0.001 \mathrm{Mg} \mathrm{C} \mathrm{ha}^{-1} \mathrm{~cm}^{-1}$ $\mathrm{y}^{-1}\left[-0.006\right.$ to -0.001 th $\left.\mathrm{C} \mathrm{ac}^{-1} \mathrm{in}^{-1} \mathrm{yr}^{-1}\right]$ to $0.017 \mathrm{Mg} \mathrm{C} \mathrm{ha}^{-1} \mathrm{~cm}^{-1} \mathrm{y}^{-1}$ (0.019 tn $\mathrm{C} \mathrm{ac}^{-1} \mathrm{in}^{-1}$ $\left.\mathrm{yr}^{-1}\right)$ increases within the surface $30 \mathrm{~cm}(11.8$ in). Addition of barnyard manure to soils under continuous wheat exhibited increases in SOC while rotations adding barnyard manure but using fallow practices continued to deplete or just maintain SOC stocks (Horner et al. 1960). In ACZ 3, Rasmussen and Parton (1994) observed continued SOC declines in the surface $30 \mathrm{~cm}$ following 55 years of barnyard manure and pea vine residue incorporation, respectively, in a winter wheat-summer fallow system. There was also little change in SOC content at 30 to 60 $\mathrm{cm}$ (11.8 to 23.6 in) depth (Rasmussen and Parton 1994). Similarly, use of green manures did not reverse the decline in SOC for a win- ter wheat-summer fallow system, and losses ranged from 0.003 to $0.005 \mathrm{Mg} \mathrm{C} \mathrm{ha}^{-1} \mathrm{~cm}^{-1}$ $\mathrm{y}^{-1}$ (0.003 to 0.006 tn $\mathrm{C} \mathrm{ac}^{-1}$ in $\left.^{-1} \mathrm{yr}^{-1}\right)$ at 0 to 30 and 30 to $60 \mathrm{~cm}$, respectively (Rasmussen and Parton 1994). The SOC declines were greater over the 10-year study by Horner et al. (1960) compared to the Rasmussen and Parton (1994) 55-year study. Overall, barnyard and green manures increased SOC, but rates of change were dependent on other management practices, such as crop rotation and inclusion of fallow periods.

\section{Summary and Conclusions}

Agricultural practices have had considerable impact on SOC in the dryland cropping regions of the PNW and will greatly influence future changes in SOC. Evaluating SOC changes that occur as a result of different management practices is critical to policy makers, carbon market developers, and land managers, particularly in light of global climate change and the capacity of soil $\mathrm{C}$ sequestration to mitigate some of the rise in atmospheric concentrations of carbon dioxide $\left(\mathrm{CO}_{2}\right)$. Current PNW data were sufficient to estimate changes in SOC that would occur following conversion of native land to agricultural cropping systems, CT to NT, and from the inclusion of more perennial crops in rotation for ACZ 2 and to some extent for 
ACZs 3 and 5. Data for these scenarios were very limited, however, for ACZ 4 as well as for other management practices across all zones. Although average changes in SOC were calculated for different depths and for soil profiles as a whole, these data were quite variable. Contributing to study variability were the long-term influences of soil erosion processes and inconsistent SOC sampling and analytical protocols. Consequently, cumulative probability distributions were developed to quantify the uncertainty associated with the SOC data. Expressing soil profile data on a cumulative probability basis provided a method where the degree of certainty in obtaining a particular SOC change could be selected by the user depending on their own risk criteria. For example, using the 25th percentile of the cumulative probability function provides a conservative estimate of SOC change as $75 \%$ of soils would be expected to have values that are equal to or greater than this value. In the PNW, on a cumulative probability bases, $75 \%$ of converted native ecosystems have lost at least 0.7, 0.35, and $0.14 \mathrm{Mg} \mathrm{C}$ $\mathrm{ha}^{-1} \mathrm{y}^{-1}\left(0.31,0.16\right.$, and 0.06 tn $\left.\mathrm{C} \mathrm{ac} \mathrm{yr}^{-1}\right)$ in ACZs 2, 3, and 5, respectively. At the 25th percentile we would expect $75 \%$ of ACZs 2 and 3 would gain at least 0.21 and $0.12 \mathrm{Mg} \mathrm{C}$ $\mathrm{ha}^{-1} \mathrm{y}^{-1}$ (0.09 and 0.05 tn $\left.\mathrm{C} \mathrm{ac}^{-1} \mathrm{yr}^{-1}\right)$, respectively, under NT following conversion from CT. Compared to annual cropping systems, mixed perennial-annual systems increased mean profile SOC stocks by $1.03 \mathrm{Mg} \mathrm{C} \mathrm{ha}{ }^{-1}$ $\mathrm{y}^{-1}\left(0.46 \mathrm{tn} \mathrm{C} \mathrm{ac}^{-1} \mathrm{yr}^{-1}\right)$, and we would expect soils in ACZ 2 to gain at least $0.69 \mathrm{Mg} \mathrm{C} \mathrm{ha}^{-1}$ $\mathrm{y}^{-1}\left(0.31\right.$ tn $\left.\mathrm{C} \mathrm{ac}^{-1} \mathrm{yr}^{-1}\right)$ for $75 \%$ of locations under this management.

From a carbon credit trading standpoint, SOC should be measureable, transparent, and verifiable (Smith et al. 2007). In order to develop and maintain a viable $\mathrm{C}$ sequestration market as well as to assess agricultural sustainability, future SOC studies in the PNW should consider developing a process-oriented strategy for measuring, verifying, and monitoring management impacts on SOC. Many carbon credit programs currently require additionality, where a practice must show that SOC is sequestered beyond "business as usual" or emissions are avoided by maintaining a SOC sequestering practice (Willey and Chameides 2007). The requirement for additionality emphasizes the need for baseline SOC data that quantifies SOC under "business as usual" and is the means by which SOC under alternative management can be compared in order to determine net benefits (i.e., offsets) (Willey and Chameides 2007).

From this study, it is clear that long-term research quantifying soil organic C content under different management practices is limited. There is also concern that estimates of agricultural soil C sequestration based on a limited soil depth might overestimate the actual sequestration potential resulting from changes in tillage management. Establishment of long-term sites representing the major agricultural systems as well as the more feasible alternatives to "business as usual" for each ACZ is needed. Included in the establishment of long-term sites would be georeferenced sampling locations and a minimum of $150 \mathrm{~cm}$ (59.1 in) sampling depth where possible. Initial soil C sampling would provide baseline data to be used in conjunction with temporal sampling to evaluate the rate and amount of soil $\mathrm{C}$ changes resulting from management. These efforts should also be linked to validating $\mathrm{C}$ model(s) for the region to aid evaluation of SOC changes due to management, particularly for specific farms and sites with unique SOC situations.

\section{Acknowledgements}

The authors recognize and thank David Uberuaga, biological science technician for the USDA Agricultural Research Service, and Shawn Wetterau, former associate in research at Washington State University Crop and Soil Sciences Department, for ArcGIS assistance; Pawel Szafruga, technical assistant at Washington State University Crop and Soil Science Department, for assistance with summary calculations of total profile SOC change; Dr. Dan Long, center director and research leader for the USDA Agricultural Research Service at the Columbia Plateau Conservation Research Center, for review and comment on draft documents; and The Pacific Northwest Direct Seed Association for valued input. The research was partially funded through the Washington State University Center for Sustaining Agricultural and Natural Resources, USDA Solutions to Economic and Environmental Problems, and the Idaho Soil Conservation Commission. The authors would also like to thank the two anonymous reviewers for comments that improved the manuscript.

\section{References}

Al-Kaisi, M., M.X. Yin, and M.A. Licht. 2005. Soil carbon and nitrogen changes as affected by tillage system and crop biomass in a corn-soybean rotation. Applied Soil Ecology 30:174-191.

Balesdent, J., C. Chenu, and M. Balabane. 2000. Relationship of soil organic matter dynamics to physical protection and tillage. Soil Tillage Research 53:215-230.
Bezdicek, D., J. Hammel, M. Fauci, D. Roe, and J. Mathison. 1998. Impact of long-term no till on soil physical, chemical, and microbial properties. STEEP III Progress Report. Pullman, WA: Washington State University. pnwsteep.wsu.edu/annualreports/1998/SP38RDB.htm.

Busacca, A.J., D.K. McCool, R.I. Papendick, and D.L. Young. 1985. Dynamic impacts of erosion processes on productivity of soils in the Palouse. In Proceedings of the National Symposium on Eorison and Soil Productivity, New Orleans, Louisiana, 10-11 December, 1984, 152-169., St. Joseph, MI:American Society of Agricultural Engineers. Busacca, A.J., C.A. Cook, and D.J. Mulla. 1993. Comparing landscape-scale estimation of soil erosion in the Palouse using Cs-137 and RUSLE. Journal of Soil and Water Conservation 48(4):361- 367.

Chaplot, V., P. Podwojewski, K. Phachomphon, and C. Valentin. 2009. Soil erosion impact on soil organic carbon spatial variability on steep tropical slopes. Soil Science Society of America Journal 73:769-779.

Cook, K.V. 2007. Estimating greenhouse gas emissions from the agricultural sector in Washington State. Washington State Department of Agriculture. Natural Resource Assessment Section. Olympia, WA: Washington State Department of Agriculture.

De Jong, E., and R.G. Kachanoski. 1988. The importance of erosion in the carbon balance of prairie soils. Canadian Journal of Soil Science 68:111-119.

Douglas, C.L., R.W. Rickman, B.L. Klepper, J.F. Zuzel, and D.J. Wysocki. 1992. Agroclimatic Zones for dryland winter wheat producing areas of Idaho, Washington, and Oregon. Northwest Science 66(1):26-34

Follett, R.F. 2001. Soil management concepts and carbon sequestration in cropland soils. Soil Tillage Research 61:77-92.

Fuentes, J.P., M. Flury, and D.F. Bezdicek. 2004. Hydraulic properties in a silt loam soil under natural prairie, conventional till, and no-till. Soil Science Society of America Journal 68:1679-1688.

Granatstein, D.M., D.F. Bezdicek, V.L. Cochran, L.F. Elliott, and J. Hammel. 1987. Long-term tillage and rotation effects on soil microbial biomass, carbon, and nitrogen. Biology and Fertility of Soils 5:265-270.

Halvorson, A.D., B.J. Weinhold, and A.L. Black. 2002. Tillage, nitrogen, and cropping system effects on soil carbon sequestration. Soil Science Society of America Journal 66:906-912.

Hassink, J., and A.P. Whitemore. 1997. A model of physical protection of organic matter in soils. Soil Science Society of America Journal 61:131-139.

Horner, G.M., M.M. Oveson, G.O. Baker, and W.W. Pawson. 1960. Effect of cropping practices on yield, soil organic matter and erosion in the Pacific Northwest wheat region. Washington, Idaho, and Oregon Agricultural Experiment Station and ARS-USDA Coop. Bull. No. 1. Pullman, WA: USDA Agricultural Research Service.

Huggins, D.R., R.R. Allmaras, C.E. Clapp, J.A. Lamb, and G.W. Randall. 2007. Corn-soybean sequence and tillage 
effects on soil carbon dynamics and storage. Soil Science Society of America Journal 71:145-154.

Huggins, D.R., G.A. Buyanovsky, G.H. Wagner, J.R. Brown, R.G. Darmody, T.R. Peck, G.W. Lesoing, M.B. Vanotti, and L.G. Bundy. 1998. Soil organic C in the tallgrass prairie-derived region of the Corn Belt: Effects of long-term crop management. Soil Tillage Research 47:219-234.

Huggins, D.R., and C. Kruger. 2010. Precision conservation: Site-specific trade-offs of harvesting wheat residues for biofuel feedstocks. In Proceedings of the 10th International Conference on Precision Agriculture, ed. R. Khosia, Denver, Colorado, USA. July 18-21, 2010. International Society of Precision Agriculture.

Ismail, I., R.L. Blevins, and W.W. Frye. 1994. Long-term no tillage effects on soil properties and continuous corn yields. Soil Science Society of America Journal 58:193-198.

Karlen, D.L., M.J. Rosek, J.C. Gardner, D.L. Allan, M.J.Alms, D.F. Bezdicek, M. Flock, D.R. Huggins, B.S. Miller, and M.L. Staben. 1999. Conservation Reserve Program effects on soil quality indicators. Journal of Soil and Water Conservation 54(1):439-444.

Lal, R., 2001. Keynote: Soil conservation for C sequestration. In 2001 Sustaining the Global Farm, eds. D.E. Stott, R.H. Mohtar, and G. C. Steinhardt, Selected papers from the 10th International Soil Conservation Organization Meeting, Purdue University and the USDA Agricultural Research Service Soil Erosion Research Laboratory, May 24-29, 1999, 459-465.

Lal, R. 2004. Soil carbon sequestration impacts on global climate change and food security. Science 304:1623-1627.

Lal, R., J.M. Kimble, R.F. Follett, and C.V. Cole.1998. The potential of US cropland to sequester carbon and mitigate the greenhouse effect. Chelsea: Sleeping Bear Press Inc.

Liebig, M.A., J.A. Morgan, J.D. Reeder, B.H. Ellert, H.T. Gollany, and G.E. Schuman. 2005. Greenhouse gas contributions and mitigation potential of agricultural practices in northwestern USA and western Canada. Soil Tillage Research 83:25-52.

Montgomery, J.D., A.J. Busacca, B.E. Frazier, and D.K. McCool. 1997. Evaluating soil movement using 137 Cs and Revised Universal Soil Loss Equation. Soil Science Society of America Journal 61:571-579.

Paustian, K., O. Andren, H.H. Janzen, R. Lal, P. Smith, G. Tian, H. Tiessen, M.Van Noordwijk, and P.L. Woomer. 1997. Agricultural soils as a sink to mitigate CO2 emissions. Soil Use Manage 13:230-244.

Post, W.M., and K.C. Kwon. 2000. Soil carbon sequestration and land-use change: Processes and potential. Global Change Biology 6:317-327.

Purakayastha, T.J., D.R. Huggins, J.L. Smith. 2008. Carbon sequestration in native prairie, perennial grass, no-till, and cultivated Palouse silt loam. Soil Science Society of America Journal 72(2):534-540.
Rasmussen, P.E., and H.P. Collins. 1991. Long-term impacts of tillage, fertilizer, and crop residue on soil organic matter in temperate semiarid regions. Advances in Agronomy 45:93-134.

Rasmussen, P.E., and W.J. Parton. 1994. Long-term effects of residue management in a wheat-fallow: I. Inputs, yield, and soil organic matter. Soil Science Society of America Journal 58:523-530.

Rasmussen, P.E., and C.R. Rohde. 1988. Long-term tillage and nitrogen fertilization effects on organic nitrogen and carbon in a semiarid soil. Soil Science Society of America Journal 52:1114-1117.

Rodman, A.W. 1988. The effect of slope position, aspect, and cultivation on organic carbon distribution in the Palouse. Master's thesis. Pullman,WA:Washington State University.

Sanchez-de Leon, Y. 2007. Carbon dynamics and earthworm populations in grassland ecosystems of the Palouse region. $\mathrm{PhD}$ dissertation. Moscow, ID: University of Idaho.

SAS Institute Inc. 2009. SAS OnlineDoc 9.2. Cary, NC: SAS Institute Inc.

Schillinger, W.F., A.C. Kennedy, D.L. Young. 2007. Eight years of annual no-till cropping in Washington's winter wheat-summer fallow region. Agriculture, Ecosystems, and Environment 120:345-358.

Sievers, FJ., and H.F. Holtz. 1922.The silt loam soils of eastern Washington. Washington Agricultural Experiment Station Bulletin No. 166. Pullman, WA: State College of Washington.

Sievers, FJ., and H.F. Holtz. 1923. The influence of precipitation on soil composition and on soil organic matter maintenance. Washington Agricultural Experiment Station Bulletin No. 176. Pullman, WA: State College of Washington.

Sievers, FJ., and H.F. Holtz. 1926. The significance of nitrogen in soil organic matter relationships. Washington Agricultural Experiment Station Bulletin No. 206. Pullman, WA: State College of Washington.

Six, J., H. Bossuyt, S. Degryze, K. Denef. 2004. A history of research on the link between (micro) aggregates, soil biota, and soil organic matter dynamics. Soil Tillage Research 79:7-31.

Smith, P. 2004. Soils as carbon sinks: The global context. Soil Use and Management. 20:212-218.

Smith, P., D. Martino, Z. Cai, D. Gwary, H. Janzen, P. Kumar, B. McCarl, S. Ogle, F. O'Mara, C. Rice, B. Scholes, O. Sirotenko. 2007. Agriculture. In Climate Change 2007: Mitigation. Contribution of Working Group III to the Fourth Assessment Report of the Intergovernmental Panel on Climate Change, eds.B. Metz, O.R. Davidson, P.R. Bosch, R. Dave, L.A. Meyer, Cambridge and New York: Cambridge University Press.

Sperow, M., M. Eve, and K. Paustian. 2003. Potential Soil C Sequestration on US agricultural soils. Climate Change 57:319-339.

Sullivan, M.D., N.R. Fausey, and R. Lal. 1997. Long-term effects of subsurface drainage on soil organic carbon content and infiltration in the surface horizons of a lakebed soil in northwest Ohio. In Management of Carbon Sequestration in Soil, eds. R. Lal, J.M. Kimble, R.F. Follett, and B.A. Stewart, 73-82 Boca Raton, FL: CR Press.

VandenBygaart, A.J., X.M Yang, B.D. Kay, and J.D. Aspinall. 2002. Variability in carbon sequestration potential in no-till soil landscapes of southern Ontario. Soil Tillage Research 65:231-241.

West, T.O., and G. Marland. 2001. A synthesis of carbon sequestration, carbon emissions, and net carbon flux in agriculture: Comparing tillage practices in the United States. Agriculture, Ecosystems, and Environment 91:217-232.

West, T.O., and W.M. Post. 2002. Soil organic carbon sequestration rates by tillage and crop rotation: A global data analysis. Soil Science Society of America Journal 66:1930-1946.

Willey, Z., and B. Chameides, eds. 2007. Step 2: Determining additionality and baselines. In Harnessing Farms and Forests in the Low-Carbon Economy: How to Create, Measure, and Verify Greenhouse Gas Offsets. 46-51. Durham, NC: Duke University Press. 